\title{
Should we reject animal source foods to save the planet? A review of the sustainability of global livestock production
}

\author{
J.L. Capper ${ }^{\#}$ \\ Livestock Sustainability Consulting, Bozeman, MT 59718, USA
}

\begin{abstract}
Copyright resides with the authors in terms of the Creative Commons Attribution 2.5 South African Licence.
See: http://creativecommons.org/licenses/by/2.5/za

Condition of use: The user may copy, distribute, transmit and adapt the work, but must recognise the authors and the South African Journal of Animal Science.
\end{abstract}

\begin{abstract}
Within the next 40 years, the global livestock industry will have to considerably increase production in order to supply the population with animal-source foods, yet the industry must concurrently improve the three metrics of sustainability - economic viability, environmental stewardship and social responsibility. Environmental stewardship is currently the area for which animal agriculture is under the most scrutiny, as many consumers perceive that animal-source foods have an unacceptable environmental cost. These concerns are intensified by activist group campaigns propounding that reducing meat consumption will have significant environmental mitigation effects. Animal-source foods have been shown to be essential dietary components for improving health of inhabitants in developing regions, for whom such foods are often economically unavailable. Moreover, reducing meat consumption in developed countries has a negligible effect upon national greenhouse gas (GHG) emissions and leads to further questions with regards to the implications for use of animal and plant by-products, and the difficulty of producing human food crops on grazed pasturelands. Improving livestock productivity has positive sustainability implications as it reduces resource use and GHG emissions whilst improving economic viability, yet it is often difficult to attain consumer acceptance of modern best practices and technologies. Productivity metrics that enhance sustainability include milk and meat yield, growth rates, feed efficiency, calving rate, parasite control and use of growth-enhancing technologies.
\end{abstract}

Keywords: Beef, dairy, carbon footprint, environmental impact, economics, social responsibility, resource use

\#E-mail: jude.capper@montana.edu

\section{Introduction}

The global human population contains over seven billion people at present. By the year 2050, the Population Division of the United Nations (2011) predicts that the planet will support more than nine billion people, of which eight billion will live in the developing world, and that the population will exceed ten billion by the year 2100. According to the Food and Agriculture Organization (FAO) of the United Nations, demand for food, fuel, and fibre will thus increase by 70\% by the year 2050 (FAO, 2009a). The seeming discrepancy between the increase in food demand and the extent of population growth is due to projected region-specific changes in population growth and affluence over time. Increases in the per capita income within China, India and Africa over this time period will result in considerable increases in animal-source food consumption (FAO, 2009b; Masuda \& Goldsmith, 2010). Thus, unless major changes in diet preferences occur, livestock production will have to substantially increase over the next 40 years to supply global demand.

Livestock system sustainability is currently one of the most highly-debated issues within food production. Livestock provide high-quality animal-source foods in conjunction with a myriad of associated economic and social benefits to communities worldwide. Nonetheless, the question is often raised as to whether the consumption of milk and meat is inherently unsustainable. The sustainability concept may be partitioned into three components: environmental stewardship, economic viability, and social responsibility (United Nations, 2005). For a region, industry or system to achieve sustainability, all three components must 
balance - if one factor is misaligned, ignored, or the sole focal point, then long-term sustainability is impossible. For example, in a region where per capita income is low and animal-source foods are not readily available to all, economic metrics (retail price) and social responsibility (food security) may take precedence over environmental metrics, yet long-term system viability will suffer if adequate attention is not paid to air quality, water cleanliness and land use. Sustainability is not an absolute state, however, thus no single system can be designated as definitively sustainable or non-sustainable. Rather, sustainability can be thought of as a process within which systems are more or less sustainable, changing over time and only moving forwards through continuous improvement. No "magic bullet" or suite of production practices exists to achieve global sustainability - individual production systems must be tailored to the resources, climate and culture indigenous to that region. This paper will discuss the challenges facing livestock sustainability at the global, regional and system level, and the opportunities moving forwards.

\section{Sustainability Issues in Developing vs. Developed Regions}

Addressing global sustainability presents substantial challenges because issues, opportunities, and resources vary considerably within and between regions. The Brundtland Report provides what is arguably the most widely used definition of sustainable development, which is that it "meets the needs of the present without compromising the ability of future generations to meet their own needs" (United Nations World Commission on Environment and Development, 1987). This implies the need to use resources at rates that do not exceed the earth's capacity to replenish them while ensuring human food security. As 870 million people are currently considered to be food insecure on a global basis (FAO, 2012b), global food production could be argued to be unsustainable as per the first half of the definition. Nonetheless, a sustainable food system is not simply dependent upon producing sufficient food, but the food reaching the consumer.

Principal farm-level sustainability concerns in developing regions currently focus on limited food availability due to low agricultural yields, lack of producer education, and inadequacies of transport and sanitary infrastructure (Godfray et al., 2010). Wider issues of concern include political instability, lack of wide-scale education (particularly for women, who are often the main agricultural workers) and military conflict (Pinstrup-Andersen, 2000). The importance of animal-source foods in maintaining the health and nutritional status of inhabitants of developing countries, for whom the supply of high-quality protein is often limited, is well recognized (Neumann et al., 2002; Murphy \& Lindsay, 2003; Randolph et al., 2007; Smith et al., 2012). Indeed, prevention of protein-energy malnutrition, iron-deficiency anaemia, and vitamin A deficiency through consumption of animal-source foods improves global longevity by a total of 33.6 million disability-adjusted life years (World Health Organization, 2009). The social and economic importance of livestock ownership in developing countries cannot be underestimated, as they have significant benefits in terms of fertiliser and draught power; as capital assets and sources of improved income, wealth storage and agricultural diversification; and through provision of provide cultural wealth and status (Randolph et al., 2007; Godfray et al., 2010; McDermott et al., 2010; Smith et al., 2012). According to the FAO (2012a), almost one billion households rely on livestock for their livelihood.

Within the developed world, the environmental impact of livestock production is arguably the greatest sustainability concern. Resource use, waste output, and greenhouse gas (GHG) emissions from livestock production are currently under scrutiny from a variety of groups ranging from global scientific associations (FAO, 2006) to activist groups (Koneswaran \& Nierenberg, 2008; Goodland \& Anhang, 2009; Environmental Working Group, 2011). The scientific consensus is that animal agriculture uses a considerable amount of resources (both renewable and nonrenewable) and makes a significant contribution to GHG emissions (FAO, 2006; Pelletier \& Tyedmers, 2010), yet the magnitude of livestock's contribution is under debate. To use GHG emissions as an example, IPCC (2007) cited agriculture as contributing 14\% of global GHG emissions; FAO (2006) estimated that animal agriculture accounts for $18 \%$ of global GHG emissions, whereas the World Watch Institute (Goodland \& Anhang, 2009) claim that 51\% of global GHG emissions result from animal agriculture. The crucial factor that is often missed in these comparisons, especially those produced by groups with an announced (or latent) agenda that is contrary to the promotion of livestock production, is that all foods have an environmental cost and that this is not restricted to foods of animal origin. Nonetheless, the supposition often occurs that global sustainability and food security could easily be achieved if a vegetarian or vegan diet was adopted worldwide. 


\section{Limitations of the Global Vegetarian/Vegan Ideology}

Recently emerged global campaigns such as "Meatless Mondays" or "Meat Free Mondays" act as a significant force behind the emerging consumer conviction that animal protein consumption is environmentally unhealthy, and thus socially irresponsible. These movements are often supported by scientific literature examining the environmental impact of reduced meat consumption (Pimentel \& Pimentel, 2003; Millward \& Garnett, 2010). For example, Weber \& Matthews (2008) conclude that "Switching less than one day per week's worth of calories from red meat and dairy products to chicken, fish, eggs or a vegetable-based diet achieves more greenhouse gas reductions than buying all locally-sourced food". Despite the lack of a control comparison in this statement, it is often used as justification for "meatless" campaigns, as are a variety of human health and environmental claims (The Monday Campaigns Inc., 2013). The impact of reduced meat consumption varies considerably between regions however, and should be examined in the context of ensuring optimum human health. It is entirely possible to achieve a balanced vegetarian diet (although more difficult for vegans, especially growing children or pregnant women) and denizens of developed regions could arguably reduce their animal-source food consumption without conferring major negative health effects. Yet the impact of removing sources of highly-digestible essential macro- and micro-nutrients from the diets of inhabitants of developing regions could have a significant detrimental effect on human wellbeing (Millward \& Garnett, 2010; Smith et al., 2012). Within developing regions, the average person consumes approximately $25 \%$ of the daily allowance of dairy products recommended for optimum health (Blaskó, 2011) and nutritional deficiencies associated with a lack of animal-source foods include low birthweights, impaired cognitive and motor development, rickets and anaemia (Neumann et al., 2002; Traoré et al., 2012).

The average U.S. inhabitant is supplied with $554 \mathrm{~kg}$ of animal-source foods (including milk, meat, fish and eggs) per year (FAO, 2013), yet within this region, the claims for a significant improvement in environmental impact through reduced meat consumption appear to be over-exaggerated. The US Environmental Protection Agency (EPA) cites meat production as contributing $2.1 \%$ of annual GHG emissions (US EPA, 2012). To take the simplistic view that a one-day per week reduction in meat consumption would cut animal production by one-seventh, if every one of the USA's 313 million inhabitants adopted such a dietary change, the projected annual reduction in national GHG emissions would be equal to $0.30 \%$. It's somewhat difficult to view a change that reduces national GHG emissions by less than one-third of one percent as having a meaningful environmental impact. Given that livestock production's GHG emissions are expressed on a percentage basis, similar calculations for other regions would yield different results depending on the balance between industry and agriculture. For example, total agriculture accounts for approximately 9.3\% of GHG emissions in South Africa (Mwakasonda et al., 2009), whereas animal agriculture alone is estimated to account for $11 \%$ of Australian annual GHG emissions (Department of Climate Change, 2010). However, the dairy and beef export markets in Australia are of considerably greater magnitude than those in the USA (e.g. $60 \%$ of Australian beef is exported compared to $~ 10 \%$ of US beef), thus the overall national impact of any "Meatless" initiative would have to account for meat production for the domestic market alone.

One often unspoken consequence of whole-scale conversion to vegetarianism or veganism is that in the event of livestock production being eliminated, agricultural animals would not exist, save for being housed within zoos or conservation parks. A large-scale reduction in meat consumption would therefore not only require the replacement of animal products with plant-based foods, but additional sources being required for the multifarious by-products from animal agriculture, including hides, fertiliser, tallow and pharmaceuticals. It is not yet clear what would be the global environmental impact of replacing leather with hydrocarbon-based synthetics, or manure with inorganic fertilisers.

One of the most commonly-heard arguments for converting to a vegetarian or vegan diet is that the global human nutrient requirements could be met simply shifting the grains currently fed to livestock to human food (Pimentel \& Pimentel, 2003). Such theories are often accompanied by claims that it takes 10, 20 or even $30 \mathrm{~kg}$ of grain to produce a $\mathrm{kg}$ of beef (Palmquist, 2011). Biologically, such feed conversion efficiencies are implausible - the average feedlot animal (fed a corn-based diet) has a feed : gain ratio of approximately 7.8 (Arthur et al., 2001) and corn only accounts for $7 \%$ of the total feed used to produce a $\mathrm{kg}$ of beef in the USA (Capper, 2011a). Furthermore, assuming that the corn currently grown for animal consumption could be replaced by a similarly-yielding human-edible variety, global corn production would need to increase by $21 \%$ in order to fulfil the nutrient requirements of the current 7 billion people on the 
planet (author's calculation). Admittedly, this is a scenario where the entire calorific intake is supplied by corn, which is implausible. Yet when the additional land and resources required to grow other, loweryielding vegetable crops to maintain dietary variety (e.g. salad leaves, asparagus and Brussels sprouts) is included in the calculation, whole-scale conversion to vegetarianism or veganism appears to be a considerable challenge.

The relatively low feed conversion efficiency of plant-based feedstuffs into animal proteins is likely to remain one of the biggest arguments against the omnivorous diet; yet is also one of the major advantages of livestock production, specifically production of high-quality proteins from human-inedible forages within ruminant systems. When comparing resource use for various human diets, Fairlie (2010) noted that converting from a conventional omnivorous diet to a vegan diet would reduce overall land use, yet the reduction was almost entirely confined to pasture land used for grazing. The quantity of land used to produce annual crops was increased in Fairlie's vegan scenario both due to the lack of animal manures for fertiliser (therefore lower crop yields) and the need to provide vegetable-based fats and oils for energy within the human diet. Globally, over 3 billion ha of pastureland are currently used to raise livestock, leading to the suggestion that this quantity of land could be far better employed for the production of human food crops. However, only a small proportion of grazed pasturelands are suitable for food crop production due to terrain, water or nutrient restrictions.

In addition to grazed forages, by-products from the human food and fibre industries play a significant role in feeding livestock worldwide. Globally, a wide variety of by-products are used ranging from fruits and vegetables (e.g. apple pomace, almond hulls or hominy) and animal by-products (e.g. blood, fish or feather meal) to waste from the processing or retail industries (e.g. bakery products or candy). By-product feeds vary considerably depending on region, system and animal species, yet there is a paucity of data is available on the absolute quantities of by-product feeds fed to livestock either on a regional or national basis (Sapkota et al., 2007). However, Gill (1999) estimated that 37 kilograms (kg) of by-product feeds suitable for livestock are produced from every $100 \mathrm{~kg}$ of plants grown for human food.

In contrast to ruminant systems that are founded upon forages, monogastric animals are fed relatively high proportions of human-edible grains in many developed regions (Wilkinson, 2011). Although by-product feeds are used in both ruminant and monogastric systems, the improved feed efficiency of monogastric animals is often cited as a rationale for reducing consumption of beef and dairy vs. pork and chicken (Brown, 2006), despite the quantities of human-edible grains used for monogastric feed. Given the increase in global food production required to meet the projected increase in population, assessing feed efficiency per unit of human-edible energy or protein input vs. output rather than via the traditional mass-based approach may therefore be a better metric when assessing livestock sustainability. Conventional measures of feed efficiency are approximately $1.1 \mathrm{~kg}$ feed/kg output for dairy, $7.8 \mathrm{~kg}$ feed/kg output for beef, $3.6 \mathrm{~kg}$ feed/kg output for pork and $2.0 \mathrm{~kg}$ feed/kg output for poultry meat, however, Wilkinson (2011) reported that both dairy and forage-fed beef cattle produce a greater amount of human-edible food than they consume due to the quantities of forage used within the diet. Revised feed efficiency ratios quoted by Wilkinson (2011) were $0.71 \mathrm{~kg}$ and $0.92 \mathrm{~kg}$ human-edible protein input per $\mathrm{kg}$ of human-edible protein output for dairy and foragefed beef respectively; with lamb, swine, poultry and corn-fed beef having feed efficiency ratios between 1.1 and $3.0 \mathrm{~kg}$ human-edible protein input per kg of human-edible protein output. Given the amino acid balance and bioavailability of iron and other nutrients within animal proteins compared to plant-based foods, this strengthens the rationale for maintaining human omnivorous diets.

\section{The Environmental Impact of Livestock Production}

Environmental impact is a multifactorial issue, although it is often discussed with sole reference to GHG emissions. Climate change is an area of considerable concern for producers, retails and policy-makers, however, resource scarcity (specifically water, land, inorganic fertilisers and fossil fuels) may be argued to have a greater immediate effect upon food production than climate change. Livestock production has a variety of direct environmental impacts upon water and air quality, nutrient leaching, soil erosion and biodiversity that should be included in environmental assessments. Indeed, Van Calker et al. (2005) report that global warming was only ranked $6^{\text {th }}$ out of eight issues considered to be important environmental sustainability issues relating to dairy production. Nonetheless, the majority of studies to date have concentrated on GHG as the sole arbiter of environmental impact. In many cases, a reduction in GHG emissions is associated with reduced resource use (Capper et al., 2008; 2009; Capper, 2011a; 2012; Capper 
\& Hayes, 2012), thus GHG will be assumed to be a valid proxy for environmental effects in the following discussion unless otherwise stated.

Agricultural GHG emissions were estimated by Bellarby et al. (2008) to account for between $17 \%$ and $32 \%$ of all global anthropogenic emissions, with the aforementioned reports by the FAO (2006) and the World Watch Institute (Goodland \& Anhang, 2009) concluding that animal agriculture contributes 18\% and $51 \%$ of GHG emissions respectively. Ruminant livestock are often considered to confer the greatest contribution to total environmental impact when compared to their monogastric cohorts due to a combination of reductions in feed efficiency and the enteric methane production from rumen digestion. For example, dairy production accounts for approximately $2.7 \%$ of worldwide GHG emissions, with average emissions of $2.4 \mathrm{~kg} \mathrm{CO}$-eq/kg FPCM (fat and protein-corrected milk) at the farm-gate (FAO, 2010). However, global averages are somewhat meaningless, as they are not representative of any specific region or system and thus offer little opportunity for practical mitigation. The FAO (2010) report revealed significant regional variation exists in GHG emissions from dairy, ranging from $1.3 \mathrm{CO}_{2}$-eq $/ \mathrm{kg}$ FPCM in North America (average milk yield of $8900 \mathrm{~kg} / \mathrm{y}$ ) to $7.5 \mathrm{~kg} \mathrm{CO}$ C $^{-}$eq/ $/ \mathrm{kg}$ FPCM in sub-Saharan Africa (average milk yield of $300 \mathrm{~kg} / \mathrm{y}$ ). It appears therefore that a negative correlation exists between milk yield and carbon footprint - as production intensity and milk yield decrease with a regional shift from the developed to the developing world, GHG emissions increase per unit of milk.

Several comparative studies have shown beneficial environmental effects of improving productivity (carcass weight and/or growth rate) within the beef sector (Capper, 2012; Capper \& Hayes, 2012; Pelletier et al., 2012; White \& Capper, 2012), thus a correlation would be expected when comparing regional beef production systems. However, this is not borne out by published literature, which exhibit considerable variation (Figure 1), reporting a range of GHG emissions per $\mathrm{kg}$ beef for intensive systems ranging from

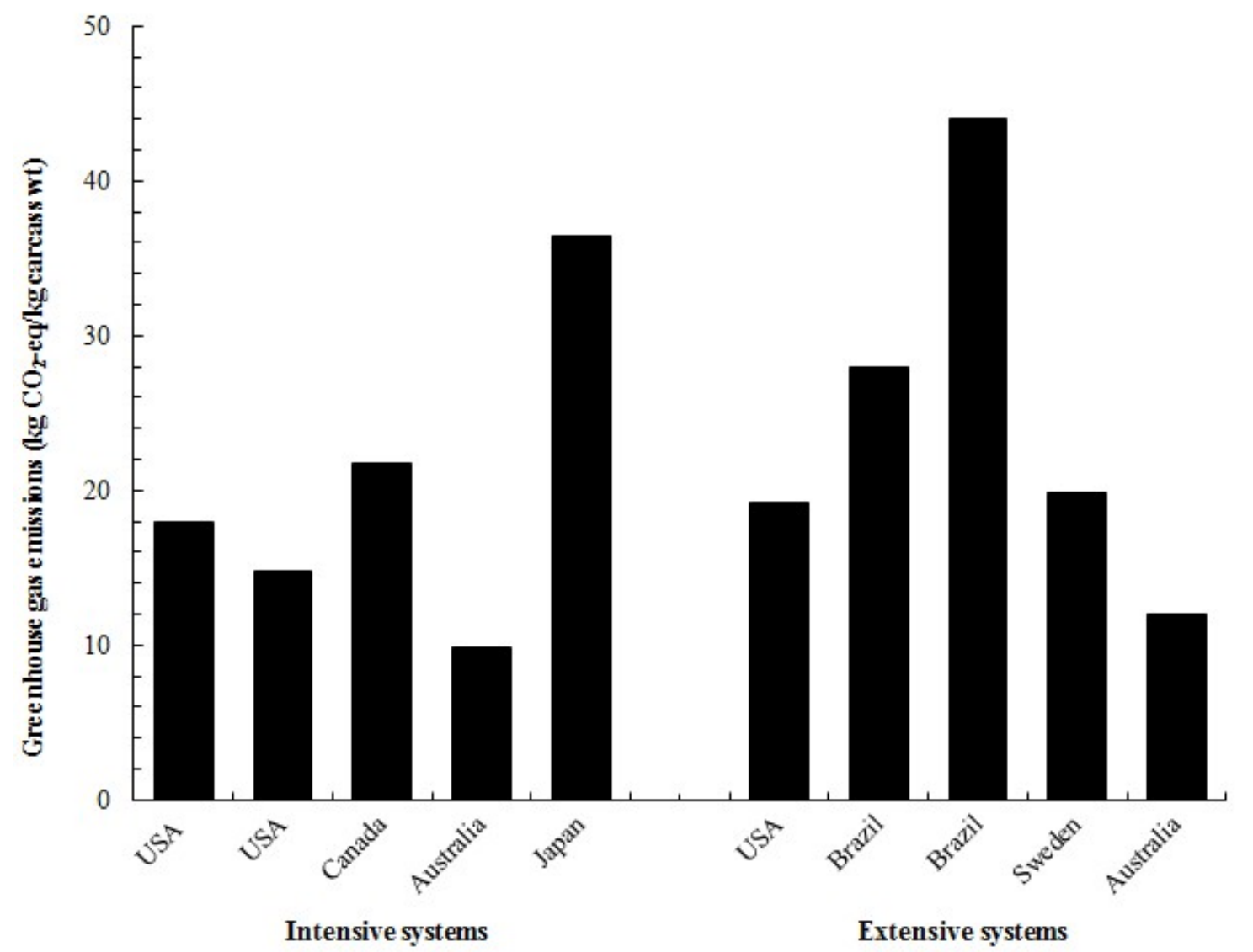

Figure 1 Regional variation in greenhouse gas emissions from beef production. Adapted from Capper (2011b) 
$9.9 \mathrm{~kg} \mathrm{CO}$-eq to $36.4 \mathrm{CO}_{2}$-eq, compared to extensive systems at 12.0 - $44.0 \mathrm{~kg} \mathrm{CO}$-eq $/ \mathrm{kg}$ beef (Ogino et al., 2004; Cederberg et al., 2009; 2011; Beauchemin et al., 2010; Pelletier et al., 2010; Peters et al., 2010; Capper, 2012). This range in reported results may not be a direct consequence of production system variation, but can be attributed to differences in methodology - variation in the system boundaries, underlying assumptions and model complexity have a considerable effect upon the results of environmental impact assessments (Bertrand \& Barnett, 2011). Until a global analysis of beef production's environmental impact is conducted, with similar methodology for each region, it is difficult to draw firm conclusions as to the variation within and between sectors.

The environmental mitigation effect of improved productivity within dairy and beef is conferred by the "dilution of maintenance" concept as shown in Figure 2 (Capper et al., 2008; Capper, 2011a). Every animal in the herd has a daily maintenance nutrient requirement that can be considered as a proxy for resource use (e.g. feed, land, water) and GHG emissions. As productivity (milk yield, meat yield or growth rate) increases, the proportion of daily energy allocated to maintenance decreases and the maintenance requirement of the total animal population decreases. If milk or meat yield increases, a set quantity of milk or meat can be produced from a herd with a reduced total bodyweight due to fewer total animals (Capper et al., 2009; Capper, 2011a), whereas an improvement in growth rate does not affect total herd numbers (unless in conjunction with an increase in meat yield) but reduces the total days required for meat production and thus reduces herd bodyweight on a temporal basis (Capper, 2012; Capper \& Hayes, 2012; White \& Capper, 2012). As production system intensity increases, concurrent improvements in productivity and efficiency are exhibited, thus "intensive" systems tend to use fewer resources and have lower GHG emissions than "extensive" systems (Capper, 2011b). However, these improvements are not always well understood by the consumer. Consumers often have an ideological view of the perceived advantages of historical small-scale agrarian systems compared to modern agriculture, which, in combination with a renowned desire to understand how food is produced, leads to the supposition that the "good old days" were environmentally superior.

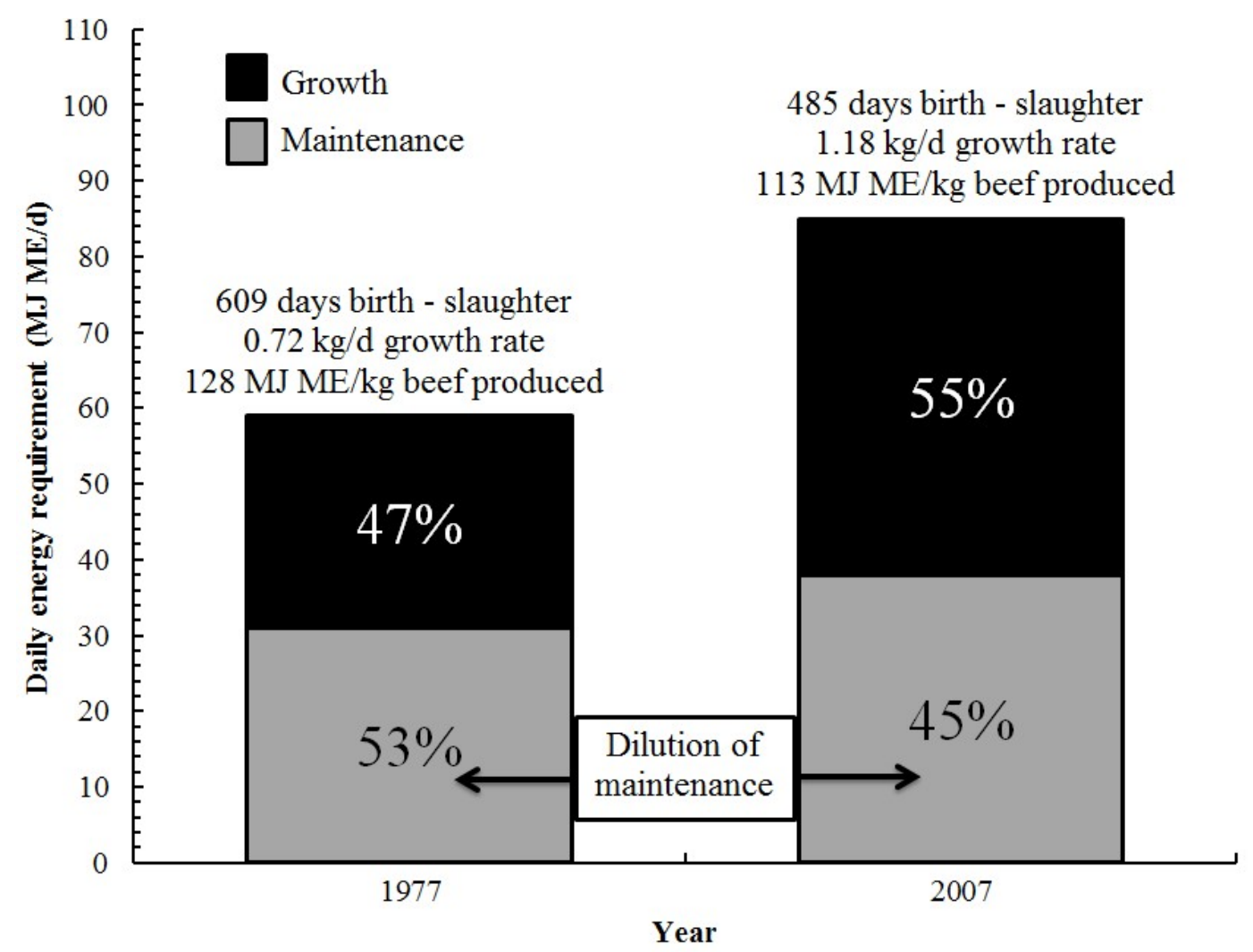

Figure 2 The "dilution of maintenance" effect as exemplified by the increase in growth rate of the average U.S. beef steer between 1977 and 2007. Adapted from Capper (2011a). 
The dichotomy between popular perception and scientific data is exemplified by comparing the U.S. dairy industries in 1944 and 2007, as reported by Capper et al. (2009). A four-fold increase in milk yield per cow over this time allowed for a 59\% increase in total milk production (53 billion kg in 1944 vs. 84 billion $\mathrm{kg}$ in 2007) whilst the national dairy herd was reduced from 25.6 million to 9.2 million cattle. This reduced feed use by $77 \%$, land use by $90 \%$, water use by $65 \%$ and conferred a $63 \%$ decrease in GHG emissions per $\mathrm{kg}$ of milk (Capper et al., 2009). Similarly, through improvements in genetics, nutrition and management between 1977 and 2007, the U.S. beef cattle industry increased average slaughter weight (607 kg in $2007 \mathrm{vs.}$ $468 \mathrm{~kg}$ in 1977) and growth rate (1.18 kg/d in $2007 \mathrm{vs.} 0.72 \mathrm{~kg} / \mathrm{d}$ in 1977) which resulted in the total average days from birth to slaughter being reduced from $609 \mathrm{~d}$ (1977) to $485 \mathrm{~d}$ (2007). In combination, these productivity improvements resulted in considerable reductions in feed (19\%), land (33\%), water (12\%) and GHG emissions (16\%) per kg of beef over the thirty-year time period, as shown in Figure 3 (Capper, 2011a).

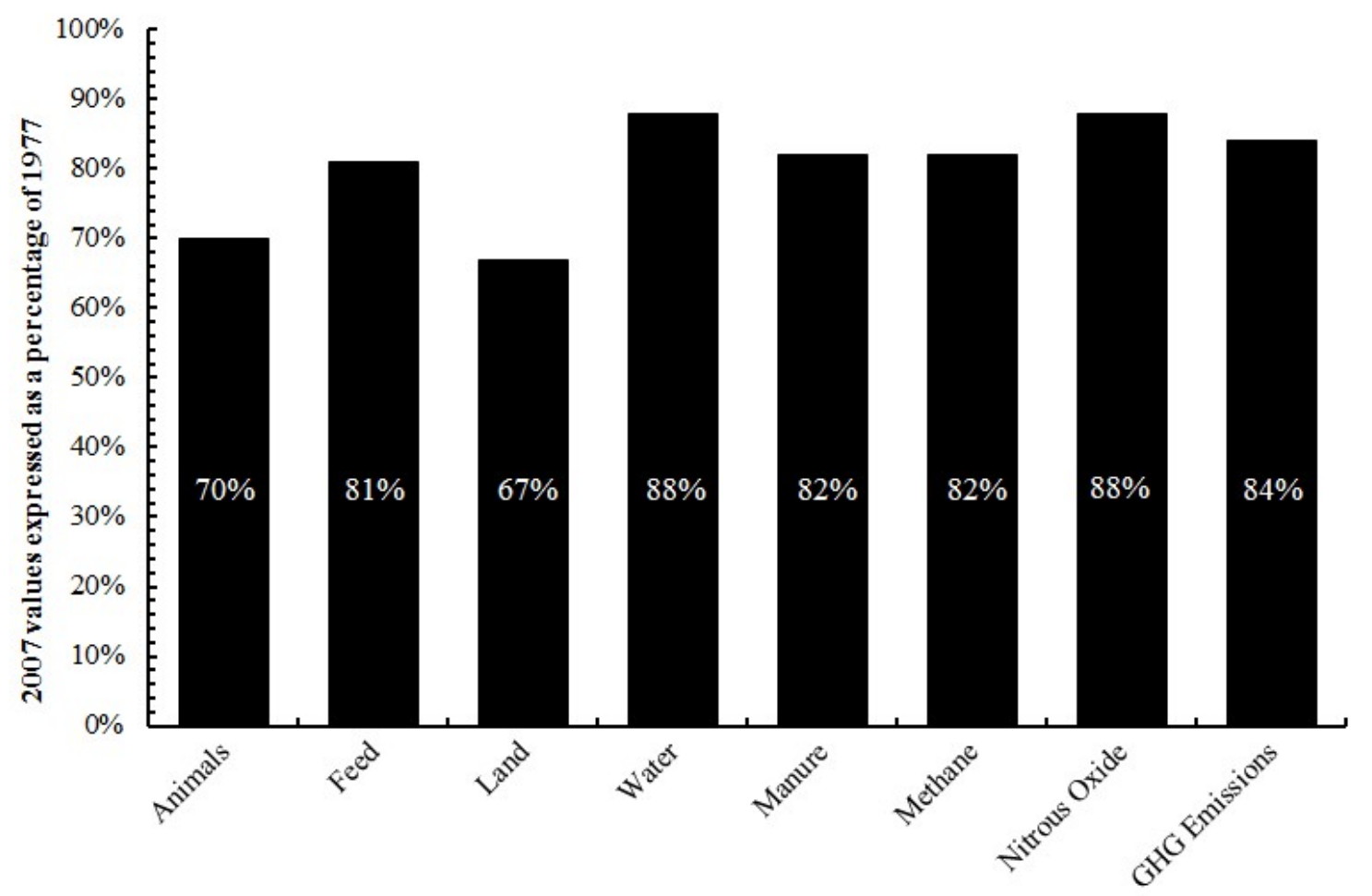

Resource use or waste output per unit of beef

Figure 3 Resource use and waste outputs per unit of beef production in the U.S. beef system in 2007 compared to a 1977 baseline at 100 percent (Capper, 2011a).

The U.S. pork industry has also reduced both resource use and GHG emissions per unit of pork over the past 50 years through similar mechanisms to those exhibited by the U.S. beef industry, i.e. increasing the number of hogs marketed from 87.6 million in 1959 to 112.6 million in 2009, from a breeding herd that has decreased in size by 39\% over the same time period (Cady et al., 2013). To date, the majority of research concentrating on reducing resource use (land, water, energy) or GHG emissions has focused on ruminant systems, yet monogastric animals also make a significant contribution, especially in terms of manure management and point-source pollution. Indeed, dietary and housing modifications aimed at reducing phosphate excretion from both poultry and swine systems have become a major focus of monogastric production in recent years. However, in contrast to ruminant systems where animals contribute the majority of resource use and emissions, Pelletier (2008) reported that feed production accounted for the major contributions to energy use, GHG emissions, acidification and eutrophication within the U.S. broiler poultry industry.

It is interesting to note that despite a the intensification of livestock production in developed regions over the past century, the proportion of GHG emissions attributed to transportation comprises less than $1 \%$ in 
conventional beef production systems (Capper, 2011a; 2012). Nonetheless, the reliance of intensive beef and dairy systems on fossil fuels and fertiliser inputs for feed production and transportation often leads to the suggestion that they have an intrinsically greater environmental impact than pasture-based extensive systems (Pollan, 2007; Salatin, 2007; Environmental Working Group, 20110). This supposition, however, does not account for reduced efficiency leading to lower meat and milk yields, and growth rates in extensive systems.

A small yet vocal section of the population advocate for a whole-scale return to the pasture-based production systems that predominated in the first half of the twentieth century within the United States (Pollan, 2007; Salatin, 2007; Environmental Working Group, 2011), yet the 52 million ha of increased land required to maintain current U.S. beef production from a wholly pasture-based system would render wholescale conversion practically impossible (Capper, 2012). If such conversion did occur and annual beef production was maintained at 11.8 billion $\mathrm{kg}$ (USDA/NASS, 2011), the increase in carbon emissions would be equal to adding 25.2 million cars to the road per year (Capper, 2012). Capper (2012) and Pelletier et al. (2010) also demonstrated that GHG emissions per unit of beef were greater in pasture-finished systems than in feedlot systems. Pelletier et al. (2010), reported GHG emissions of $19.2 \mathrm{~kg} \mathrm{CO}$-eq/kg liveweight for pasture-finished beef compared with $16.2 \mathrm{~kg} \mathrm{CO}$-eq/kg liveweight for feedlot-finished yearling-fed beef, whereas Capper (2012) reported $26.8 \mathrm{~kg} \mathrm{CO}$-eq/kg hot carcass weight beef for pasture-finished beef and $16.0 \mathrm{~kg} \mathrm{CO}$-eq/kg hot carcass weight beef for feedlot beef. Supplying the entire U.S. demand for milk through organic production systems was found by Capper et al. (2008) to confer a 13\% increase in GHG emissions per unit of milk in U.S. systems, and by Cederberg and Mattsson (Cederberg \& Mattsson, 2000) to increase GHG emissions by $15 \%$ in Swedish dairy systems. By contrast, a comparison of organic and conventional poultry systems by Boggia et al. (2010) showed that organic poultry systems exhibited superior environmental performance. Although the tendency to romanticize historical production systems and feeding systems that mimic "natural" (i.e., unmodified by human interaction) livestock systems is understandable, this ideology should not be used as a recommendation for future livestock systems without scientific foundation.

\section{Current and Future Opportunities for Improving the Environmental and Economic Aspects of Livestock Sustainability}

In their global analysis of GHG emissions from animal agriculture, the FAO (2006) conclude that sustainable intensification is crucial in order to mitigate the environmental impact of animal agriculture whilst improving productivity and global food security. Sustainable intensification is a somewhat nebulous term, yet it may be defined as a move towards improved productivity and efficiency whilst fulfilling the environmental, economic and social balance required for a sustainable system. In essence, this may be equated to a process of continuous improvement, as has been demonstrated by many livestock industries in terms of reducing environmental impact over time, whilst maintaining food affordability and social acceptability.

Improved productivity and efficiency are inherently linked to reduced losses throughout the system. These may be achieved through management practices that reduce specific environmental impacts, e.g. soil testing to assess fertiliser requirements, installation of anaerobic digesters to reduce GHG emissions, or recycling water on-farm. However, a greater mitigation effect may be achieved through whole-system approaches that impact animal productivity and allow livestock to perform to their genetic potential. If a livestock system working at optimal efficiency throughout would potentially produce a quantity of milk or meat in a given time based on animal genetic merit, every loss of productivity within the system will reduce the milk/meat yield and increase both economic cost and environmental impact per unit of food produced. One major advantage of productivity-based approaches is that they are irrespective of system (e.g. intensive vs. extensive, conventional vs. organic), operation size or region, and thus can be implemented globally according to the mechanisms and tools available within that area, with due consideration for all three sustainability facets. Productivity metrics such as milk yield, slaughter weight and growth rate have significant sustainability effects, yet other metrics must also be considered.

In many livestock industries, animal bodyweight has increased concurrently with productivity gains, thus daily resource use and GHG emissions per animal have increased (Capper et al., 2009; Capper, 2011a), although environmental impact per unit of food produced is reduced. If bodyweight in the supporting herd could be reduced without a loss of productivity, environmental and economic gains would result. Within dairy production, Capper \& Cady (2012) reported that producing cheese from Jersey cattle (average mature 
liveweight $454 \mathrm{~kg}$ ) vs. Holstein cattle (average mature liveweight $680 \mathrm{~kg}$ ) considerably reduced both resource use and GHG emissions. Within beef production, if mature beef cow bodyweight were reduced from $703 \mathrm{~kg}$ to $486 \mathrm{~kg}$ while maintaining the final carcass weight of the offspring, GHG emissions per unit of beef would decline by 13\% (author's calculation; Figure 4).

The poultry and swine industries have made significant gains in terms of improving feed efficiency over the past century, and considerable interest currently exists within the beef industry in terms of selecting cattle for improved feed efficiency. This may be achieved through an improvement in residual feed intake (RFI), i.e. reduced feed consumption requirement to support maintenance and production compared to the predicted or average quantity (Archer et al., 1999). The development of estimated breeding values (EBVs) for RFI is relatively new, yet appears to show promise as a strategy by which producers may improve efficiency. Steers selected for high efficiency (low RFI) consumed less feed over the finishing period compared to low-efficiency cohorts in a large-scale feedlot study by Herd et al. (2009) whilst maintaining slaughter weight and exhibiting a greater dressing percentage. Furthermore, Hegarty et al. (2007) reported that Angus steers selected for a lower RFI had reduced methane emissions consistent with reduced dry matter intake (DMI). If productivity may be maintained on a reduced DMI, resource use, GHG emissions and feed costs would also be predicted to decrease per unit of output.

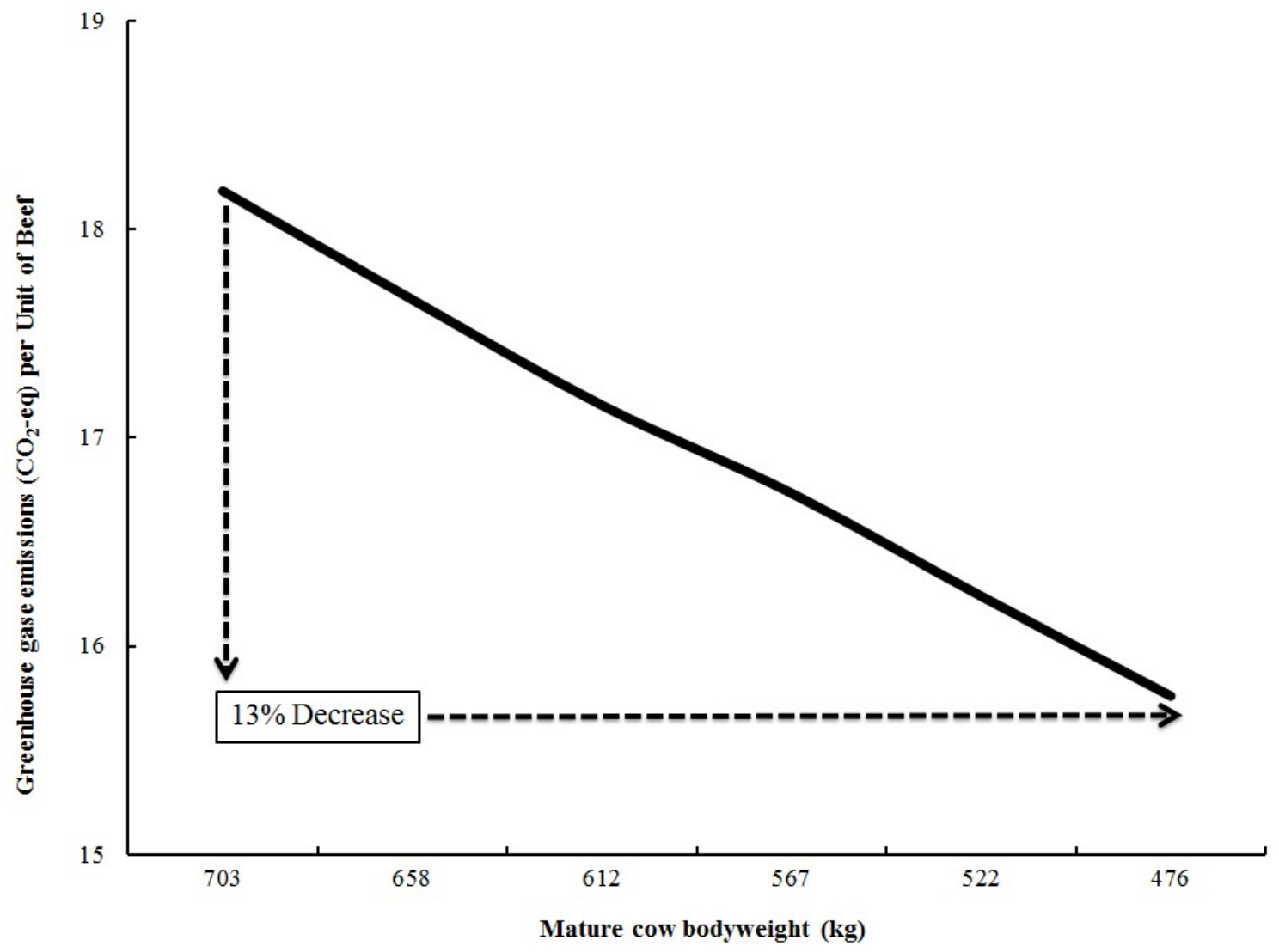

Figure 4 The effect of reducing mature beef cow bodyweight upon greenhouse gas emissions per unit of beef (author's calculation, unpublished).

Reproduction is arguably one of the most important productivity aspects within livestock production, both in order to guarantee offspring that are raised for meat, and to initiate lactation in dairy animals. The introduction of genetic selection tools over the past century has allowed for greater rates of genetic improvement and increased selection pressures for specific traits, however, these may have associated negative trade-offs. For example, breeding for increased milk yield in dairy cattle is generally considered to have contributed to declining fertility rates. Garnsworthy (2004) demonstrated that restoring fertility levels to those seen in UK dairy cattle c. 1995, or improving them to ideal levels, reduced methane emissions per unit of milk through a reduction in the number of heifer replacements required within the herd and thus a 
decrease in the herd maintenance requirement. Fertility is arguably the major factor by which global beef producers (specifically cow-calf producers) could also improve the sustainability of beef production. Within the US, 89\% of cows bear a live calf each year (USDA, 2009), and this number declines to between 50\% $60 \%$ in the extensive systems characteristic of Brazil, Argentina and Chile. Given that the cow-calf operation contributes up to $80 \%$ of GHG emissions per unit of beef (Beauchemin et al., 2010) and that productivity improvements post-calving cannot compensate for the resource use and GHG emissions associated with maintaining a non-productive cow, management practices and technologies that improve pregnancy rate offer significant opportunities. Capper (2013a) modelled the environmental and economic impact of improving calving rate from $60 \%$ to the ideal $(100 \%)$ and demonstrated reductions in land use from 3.61 ha to 2.54 ha, water use from $682 \times 10^{3}$ litres to $508 \times 10^{3}$ litres, GHG emissions from $7945 \mathrm{~kg}$ to $5459 \mathrm{~kg}$ and feed costs from \$1 924 to $\$ 1412$ per $363 \mathrm{~kg}$ hot carcass weight beef (average U.S. carcass weight).

The World Organization for Animal Health (2008) stated that globally average animal losses due to disease are more than $20 \%$, thus considerable gains could potentially be made through treating diseases or conditions that have a negative impact upon performance. For example, both Lawrence \& Ibarburu (2007) and Capper (2013c) reported that judicious use of parasiticides in beef cattle improved performance, with associated positive environmental and economic impacts. To date, however, the combined sustainability effects of many of the less-tangible productivity losses within livestock systems, e.g. male fertility, clinical and sub-clinical morbidity and growth of replacement animals have yet to be quantified.

\section{The Social Acceptability of Livestock Production}

Improving system productivity and making the most efficient use of available resources has a two-fold advantage to the producer in terms of reducing both environmental impact and the economic costs of production (Capper \& Hayes, 2012) thus contributing to economic viability. However, the social responsibility facet is often the most difficult to address. Traditional life cycle analyses focused on evaluating sustainability often concentrate upon health and welfare indicators such as workplace accidents or emissions of hazardous chemicals as the sole arbiters of social responsibility, yet these do not address the fundamental principle at the heart of the issue, i.e. that if a product is not perceived as being socially responsible and thus demand does not exist, there is no economic viability and thus no future for the system. Although survey data overwhelmingly concludes that price, taste, convenience and nutrition are the major factors affecting purchasing decisions (Vermeir \& Verbeke, 2006; Simmons, 2009), these are still dependent on the product being morally or ethically acceptable to the consumer. Lichtenstein et al. (1988) contends that consumer willingness-to-pay (WTP) is a valid indicator of the social acceptability of a product or service. The WTP concept may be criticized as a sustainability indicator as the information provided relative to consumer views and ideologies that may not be borne out by behaving behaviour - Robinson \& Smith (2002) reported that 52\% of consumers showed interest in purchasing "earth-sustainable foods", yet similar interest only translates into a change in buying behaviours for a small segment of consumers, hence the relatively small market share for niche systems such as organic, local or natural foods at present (Vermeir \& Verbeke, 2006). However, in a meta-analysis of WTP data, White \& Brady (2013) reported that consumers would pay a $4 \%$ premium for beef products perceived to have positive effects on environmental impact, which increased to an $82 \%$ premium for products with a combined environmental and health benefit. This concurs with the results of Schulz et al. (2012) who examined retail price scanner data and concluded that consumer would pay $30 \%$ more for originally-labelled beef.

Consumer aversion to the use of chemicals in food production is often cited as a retailer rationale for removing technologies such as hormones, beta-agonists or antibiotics from the food supply chain. Although the market share for organic, natural or local foods is small, it is appears to be growing, and the danger exists that technologies will be prohibited from livestock production through retailer action at a rate considerably faster than could be achieved through legislation. Technologies such as ionophores, steroid implants, hormones and beta-adrenergic agonists have had a significant role to play in improving the environmental impact of ruminant production in those regions where they are registered for use. Capper et al. (2008) reported that recombinant bovine somatotropin used within lactating dairy cows conferred reductions in land, water and fossil fuel use of $8.1 \%, 8.1 \%$, and $8.2 \%$ per unit of milk respectively, in addition to reducing GHG emissions from dairy production by $8.8 \%$. In a subsequent analysis, Capper (2013b) reported that use of steroid implants combined with beta-adrenergic agonists improved slaughter weight and growth rate, thus reducing resource use and GHG emissions. Removing production-enhancing technology (ionophores, in-feed 
hormones, steroid implants and beta-adrenergic agonists) from U.S. beef production was predicted by Capper \& Hayes (2012) to increase annual resource use, to be equivalent to imposing an $8.2 \%$ economic tax on beef producers, and to increase global GHG emissions by 3.14 billion metric tonnes over time as a consequence of reduced competitiveness of the U.S. beef production systems increasing exports from countries with less-intensive production systems. Despite considerable evaluation by national and global health agencies and the prevailing opinion that no human health threats are presented by the use of such technologies, political and social agendas often oppose the approval or registration of these product within specific regions. The input of academics, researchers, veterinarians and animal science professionals will be crucial within future debates in order to ensure that science is not lost amongst public perception or political considerations.

\section{Conclusion}

The global livestock industry faces a considerable challenge in maintaining and improving sustainability as the global population continues to increase. The onslaught of information provided by activist groups that aim to denigrate animal agriculture and the increasing chasm between consumer perceptions of sustainability vs. the reality of modern agricultural systems will continue to be a significant obstacle. The entire livestock industry has a significant role to play in helping to improve the sustainability of animal agriculture. Implementation of productivity improvements that reduce resource use and GHG emissions, improve economic viability and thus maintain the supply of affordable animal source foods to the consumer can only be achieved through collaboration between producers, veterinarians, other allied industry and academia in order to ensure that animals are bred, fed and cared for using management practices and technologies that will enable them to perform to their genetic potential. It is crucial to note that although productivity indices exist that are consistent across the global livestock industry (e.g. growth rate, milk yield or calving rate), changes in management practice must be implemented with due consideration for the system resources in terms of labour, labour, economics, market and animal characteristics. Mechanisms and programs to better educate the consumer, either directly or through retail and media channels will be essential to attempt to allow for a better understanding of livestock production and reduce the risk of animalsource foods being replaced by planted-based proteins within the human diet. No "one-size-fits-all” solution exists, yet if all systems improve economic viability, environmental stewardship and social responsibility on a global scale, the challenge of meeting human food requirements for animal-source foods in the year 2050 becomes far more achievable.

\section{References}

Archer, J.A., Richardson, E.C., Herd, R.M. \& Arthur, P.F., 1999. Potential for selection to improve efficiency of feed use in beef cattle: A review. Aust. J. Agr. Res. 50, 247-261.

Arthur, P.F., Archer, J.A., Johnston, D.A., Herd, R.M., Richardson, E.C. \& Parnell, P.F., 2001. Genetic and phenotypic variance and covariance components for feed intake, feed efficiency, and other postweaning traits in Angus cattle. J. Anim. Sci. 79, 2805-2811.

Beauchemin, K.A., Janzen, H., Little, S.M., McAllister, T.A. \& McGinn, S.M., 2010. Life cycle assessment of greenhouse gas emissions from beef production in western Canada: A case study. Agr. Syst. 103, 371-379.

Bellarby, J., Foereid, B., Hastings, A. \& Smith, P., 2008. Cool Farming: Climate Impacts of Agriculture and Mitigation Potential. Greenpeace International, Amsterdam, The Netherlands.

Bertrand, S. \& Barnett, J., 2011. Standard method for determining the carbon footprint of dairy products reduces confusion. Anim. Front. 1, 14-18.

Blaskó, B., 2011. World Importance and Present Tendencies of Dairy Sector. App. St. Agribus. Comm. 5, 119-123.

Boggia, A., Paolotti, L. \& Castellini, C., 2010. Environmental impact evaluation of conventional, organic and organic-plus poultry production systems using life cycle assessment. Wrlds Poult. Sci. J. 66, 95-114.

Brown, L.R., 2006. Plan B 2.0 Rescuing a Planet Under Stress and a Civilization in Trouble. W.W. Norton, New York, NY, USA.

Cady, R.A., Boyd, G., Wittig, L., Bryan, G., Holden, P.J., Sutton, A.L. \& Anderson, D., 2013. A 50-year comparison of the environmental impact and resource use of the U.S. swine herd: 1959 vs. 2009. In: 
Proceedings of the ADSA-ASAS Joint Annual Meeting, Indianapolis, IN, USA, held on July 8-12, 2013.

Capper, J.L., 2011a. The environmental impact of beef production in the United States: 1977 compared with 2007. J. Anim. Sci. 89, 4249-4261.

Capper, J.L., 2011b. Replacing rose-tinted spectacles with a high-powered microscope: The historical vs. modern carbon footprint of animal agriculture. Anim. Front. 1, 26-32.

Capper, J.L., 2012. Is the grass always greener? Comparing resource use and carbon footprints of conventional, natural and grass-fed beef production systems. Animals 2, 127-143.

Capper, J.L., 2013a. The environmental and economic impact of calving rate within U.S. beef production. In: Proceedings of the ADSA-ASAS Joint Annual Meeting, Indianapolis, IN, USA, held on July 8-12, 2013.

Capper, J.L., 2013b. The environmental and economic impact of steroid implant and beta-adrenergic agonist use within U.S. beef production. In: Proceedings of the ADSA-ASAS Joint Annual Meeting, Indianapolis, IN, USA, held on July 8-12, 2013.

Capper, J.L., 2013c. The environmental and economic impact of withdrawing parasite control (Fenbendazole) from U.S. beef production. In: Proceedings of the ADSA-ASAS Joint Annual Meeting, Indianapolis, IN, USA, held on July 8-12, 2013.

Capper, J.L. \& Cady, R.A., 2012. A comparison of the environmental impact of Jersey vs. Holstein milk for cheese production. J. Dairy Sci. 95, 165-176.

Capper, J.L. \& Hayes, D.J., 2012. The environmental and economic impact of removing growth-enhancing technologies from United States beef production. J. Anim. Sci. 90, 3527-3537.

Capper, J.L., Cady, R.A. \& Bauman, D.E., 2009. The environmental impact of dairy production: 1944 compared with 2007. J. Anim. Sci. 87, 2160-2167.

Capper, J.L., Castañeda-Gutiérrez, E., Cady, R.A. \& Bauman, D.E., 2008. The environmental impact of recombinant bovine somatotropin (rbST) use in dairy production. Proc. Natl. Acad. Sci. U. S. A. 105, 9668-9673.

Cederberg, C., \& Mattsson, B., 2000. Life cycle assessment of milk production - a comparison of conventional and organic farming. J. Clean. Prod. 8, 49-60.

Cederberg, C., Sonesson, U., Henriksson, M., Sund, V. \& Davis, J., 2009. Greenhouse Gas Emissions from Swedish Production of Meat, Milk and Eggs: 1990 and 2005. Swedish Institute of Food \& Biotechnology, Gothenburg, Sweden.

Cederberg, C., Persson, M., Neovius, K., Molander, S. \& Clift, R., 2011. Including carbon emissions from deforestation in the carbon footprint of Brazilian beef. Environ. Sci. Technol. 45, 1773-1779.

Department of Climate Change, 2010. National Inventory Report 2008 - Volume 1. The Australian Government Submission to the UN Framework Convention on Climate Change May 2010. Department of Climate Change, Canberra, Australia.

Environmental Working Group, 2011. Meat Eater's Guide to Climate Change and Health. Environmental Working Group, Washington, DC., USA.

Fairlie, S., 2010. Meat - A Benign Extravagance. Chelsea Green Publishing, White River Junction, VT.

FAO, 2006. Livestock's Long Shadow - Environmental Issues and Options. FAO, Rome, Italy.

FAO, 2009a. Global Agriculture Towards 2050. FAO, Rome, Italy.

FAO, 2009b. How to Feed the World in 2050. FAO, Rome, Italy.

FAO, 2010. Greenhouse Gas Emissions from the Dairy Sector: A Life Cycle Assessment. FAO, Rome, Italty.

FAO, 2012a. Livestock Sector Development for Poverty Reduction: An Economic and Policy Perspective. FAO, Rome, Italy.

FAO, 2012b. The State of Food Insecurity in the World. FAO, Rome, Italy.

FAO, 2013. FAOSTAT. Available at: http://faostat.fao.org Accessed: June 1, 2013.

Garnsworthy, P.C., 2004. The environmental impact of fertility in dairy cows: a modelling approach to predict methane and ammonia emissions. Anim. Feed. Sci. Technol. 112, 211-223.

Gill, M., 1999. Meat production in developing countries. Proc. Nutr. Soc. 58, 371-376.

Godfray, H.C.J., Beddington, J.R., Crute, I.R., Haddad, L., Lawrence, D., Muir, J.F., Pretty, J., Robinson, S., Thomas, S.M. \& Toulmin, C., 2010. Food security: The challenge of feeding 9 billion people. Science 327, 812-818. 
Goodland, R. \& Anhang, J., 2009. Livestock and Climate Change. What if the Key Actors in Climate Change were Pigs, Chickens and Cows? Worldwatch Institute, Washington, D.C., USA.

Hegarty, R.S., Goopy, J.P., Herd, R.M. \& McCorkell, B., 2007. Cattle selected for lower residual feed intake have reduced daily methane production. J. Anim. Sci. 85, 1479-1486.

Herd, R.M., Piper, S., Thompson, J.M., Arthur, P.F., McCorkell, B. \& Dibley, K.C.P., 2009. Benefits of genetic superiority in residual feed intake in a large commercial feedlot. Proc. Assn. Adv. An. Breed. Genet. 18, 476-479.

IPCC. 2007. Climate Change 2007: The Physical Science Basis. Contribution of Working Group I to the Fourth Assessment Report of the Intergovernmental Panel on Climate Change. IPCC Secretariat, Geneva, Switzerland.

Koneswaran, G. \& Nierenberg, D., 2008. Global farm animal production and global warming: impacting and mitigating climate change. Environ. Health Perspect. 116, 578-582.

Lawrence, J.D. \& Ibarburu, M., 2007. Economic Analysis of Pharmaceutical Technologies in Modern Beef Production in a Bioeconomy Era. Iowa State University, Ames, IA.

Lichtenstein, D.R., Bloch, P.H. \& Black, W.C., 1988. Correlates of price acceptability. J. Consum. Res. 15, 243-252.

Masuda, T. \& Goldsmith, P.D., 2010. China's meat consumption: An income elasticity analysis and longterm projections In: Proceedings of Agricultural \& Applied Economics Association 2010 AAEA, CAES, \& WAEA Joint Annual Meeting, Agricultural \& Applied Economics Association, Denver, CO, held on July 25-27, 2010.

McDermott, J.J., Staal, S.J., Freeman, H.A., Herrero, M. \& Van de Steeg, J.A., 2010. Sustaining intensification of smallholder livestock systems in the tropics. Livest. Sci. 130, 95-109.

Millward, D.J. \& Garnett, T., 2010. Food and the planet: nutritional dilemmas of greenhouse gas emission reductions through reduced intakes of meat and dairy foods. Proc. Nutr. Soc. 69, 103-118.

Murphy, S.P. \& Lindsay, L.H., 2003. Nutritional importance of animal source foods. J. Nutr. 133, 3932S3935S.

Mwakasonda, S., Taviv, R., Lukey, P., Witi, J., Richardson, A., Mahema, T. \& Trikam, A., 2009. Greenhouse Gas Inventory South Africa 1990 to 2000. National Inventory Report. Department of Environmental Affairs and Tourism, Pretoria, South Africa.

Neumann, C., Harris, D.M. \& Rogers, L.M., 2002. Contribution of animal source foods in improving diet quality and function in children in the developing world. Nutr. Res. 22, 193-220.

Ogino, A., Kaku, K., Osada, T. \& Shimada, K., 2004. Environmental impacts of the Japanese beef-fattening system with different feeding lengths as evaluated by a life-cycle assessment method. J. Anim. Sci. 82, 2115-2122.

Palmquist, D., 2011. Can the World Feed Itself Without Ruining the Planet? Available at: http://blog.nature.org/2011/10/can-the-world-feed-itself-without-ruining-the-planet/ Accessed: June 1, 2013.

Pelletier, N., 2008. Environmental performance in the US broiler poultry sector: Life cycle energy use and greenhouse gas, ozone depleting, acidifying and eutrophying emissions. Agr. Syst. 98, 67-73.

Pelletier, N. \& Tyedmers, P., 2010. Forecasting potential global environmental costs of livestock production 2000-2050. Proc. Natl. Acad. Sci. U.S.A. 107, 18371-18374.

Pelletier, N., Pirog, R. \& Rasmussen, R., 2010. Comparative life cycle environmental impacts of three beef production strategies in the Upper Midwestern United States. Agr. Syst. 103, 380-389.

Peters, G.M., Rowley, H.V., Wiedemann, S., Tucker, R., Short, M.D. \& Schultz, M.S., 2010. Red meat production in Australia: Life cycle assessment and comparison with overseas studies. Environ. Sci. Technol. 44, 1327-1332.

Pimentel, D. \& Pimentel, M., 2003. Sustainability of meat-based and plant-based diets and the environment. Am. J. Clin. Nutr. 78, 660S-663S.

Pinstrup-Andersen, P., 2000. Food policy research for developing countries: emerging issues and unfinished business. Food Policy 25, 125-141.

Pollan, M., 2007. The Omnivore's Dilemma. The Penguin Group, New York, NY, USA.

Randolph, T.F., Schelling, E., Grace, D., Nicholson, C.F., Leroy, J.L., Cole, D.C., Demment, M.W., Omore, A., Zinsstag, A. \& Ruel, M., 2007. Invited review: Role of livestock in human nutrition and health for poverty reduction in developing countries. Int. J. Anim. Sci. 85, 2788-2800. 
Robinson, R. \& Smith, C., 2002. Psychosocial and demographic variables associated with consumer intention to purchase sustainably produced foods as defined by the Midwest Food Alliance. J. Nutr. Educ. Behav. 34, 316-325.

Salatin, J., 2007. Everything I Want To Do Is Illegal. Polyface Farm Inc, Swoope, VA, USA.

Sapkota, A.R., Lefferts, L.Y., McKenzie, S. \& Walker, P., 2007. What do we feed to food-production animals? A review of animal feed ingredients and their potential impacts on human health. Environ. Health Persp. 115, 663-670.

Schulz, L.L., Schroeder, T.C. \& White, K.L., 2012. Value of beef steak branding: Hedonic analysis of retail scanner data. Agr. Res. Econ. Rev. 41, 260-273.

Simmons, J., 2009. Food Economics and Consumer Choice. Elanco Animal Health, Greenfield, IN, USA.

Smith, J., Sones, K., Grace, D., MacMillan, S., Tarawali, S. \& Herrero, M., 2012. Beyond milk, meat, and eggs: Role of livestock in food and nutrition security. Anim. Front. 3, 6-13.

The Monday Campaigns Inc., 2013. Why Meatless? Available at: http://www.meatlessmonday.com/whymeatless/ Accessed: June 1, 2013.

Traoré, M., Thompson, B. \& Thomas, G., 2012. Sustainable Nutrition Security: Restoring the Bridge Between Agriculture and Health. FAO, Rome, Italy.

United Nations, 2005. 2005 World Summit Outcome. United Nations Publications, New York, NY, USA.

United Nations, Department of Economic and Social Affairs, Population Division, 2011. World Population Prospects: The 2010 Revision, Volume I: Comprehensive Tables. ST/ESA/SER.A/313. United Nations, New York, NY, USA.

United Nations World Commission on Environment and Development, 1987. Our Common Future: Report of the World Commission on Environment and Development. Oxford University Press, Oxford, UK.

USDA, 2009. Beef 2007-08 Part II: Reference of Beef Cow-calf Management Practices in the United States, 2007-08. USDA:APHIS:VS, CEAH, National Animal Health Monitoring System, Fort Collins, CO, USA.

USDA/NASS, 2011. Livestock Slaughter Annual Summary. USDA, Washington, DC, USA.

US EPA, 2012. Inventory of U.S. Greenhouse Gas Emissions and Sinks: 1990-2010. US EPA, Washington, DC, USA.

Van Calker, K.J., Berentsen, P.B.M., Giesen, G.W.J. \& Huirne, R.B.M., 2005. Identifying and ranking attributes that determine sustainability in Dutch dairy farming. Agr. Hum. Val. 22, 53-63.

Vermeir, I. \& Verbeke, W., 2006. Sustainable food consumption: Exploring the consumer "attitude behavioral intention" gap. J. Agr. Environ. Ethic. 19, 169-194.

Weber, C.L. \& Matthews, H.S., 2008. Food-miles and the relative climate impacts of food choices in the United States. Environ. Sci. Technol. 42, 3508-3515.

White, R.R. \& Brady, M., 2013. Meta-analysis of consumer willingness to pay for specialty attributes of beef. In: Proceedings of the ADSA-ASAS Joint Annual Meeting, Indianapolis, IN, USA, held on July 8-12, 2013.

White, R.R. \& Capper, J.L., 2012. The environmental, economic and social implications of improving yield and average daily gain in beef production. J. Anim. Sci. 90 (Suppl. 3), 330.

Wilkinson, J.M., 2011. Re-defining efficiency of feed use by livestock. Animal 5, 1014-1022.

World Organisation for Animal Health (OIE), 2008. Feeding the world better by controlling animal diseases. Available at: http://www.oie.int/for-the-media/editorials/detail/article/feeding-the-world-better-bycontrolling-animal-diseases/ Accessed: April 18, 2012. 